\title{
ORIGINAL ARTICLE \\ CLINICAL FEATURES OF NOVEL CORONAVIRUS 2019-INFECTED CASES WITH PRE-EXISTING CARDIOVASCULAR DISEASE, DISAGGREGATED BY GENDER
}

\author{
Elham Mohammadyari' ${ }^{1}$, Mohammad Reza Kaffashian', Iraj Ahmadi ${ }^{1}$, Azra Kenarkoohi', \\ Askar Soufinia $^{1}$, Siros Norozi ${ }^{1}$, Firooz Balavandi ${ }^{1}$, Abas Ghaysouri ${ }^{1}$, Elham Bastani ${ }^{1}$, \\ Mahsa Rizehbandi ${ }^{1}$, Mohammad Karimian ${ }^{1}$, Masoud Fasihi ${ }^{1}$, Shahab Falahi ${ }^{1}$, Gholamreza \\ Kalvandi $^{2}$, Maryam Maleki ${ }^{1}$ \\ ${ }^{1}$ Ilam University of Medical sciences, Ilam, Iran, 2Hamadan University of Medical Sciences Hamadan, Iran
}

\begin{abstract}
Objectives: This study was conducted to evaluate the clinical features of 68 coronavirus 2019infected cardiac cases on gender basis.

Methodology: Clinical, laboratory and electrocardiographic data of 68 COVID-19 patients with pre-existing cardiovascular diseases, analyzed and compared by gender-wise.

Results: Dry cough (78\% of male, $80 \%$ females) and fever (62\% of male, $75 \%$ females) were the most common symptoms. Out of these $97 \%$ of them needed O2 supplementation. O2 saturation in patients with $\mathrm{O} 2$ therapy was $85 \% ; 31 \%$ of men and $11 \%$ of women experienced intubation. The most common laboratory abnormalities, were neutrophilia, leukocytosis, lymphopenia, thrombocytopenia, decreased hemoglobin level, increased creatinine and urea, in men and women. Troponin level was different between male and female. Pneumonia was found in $86-87 \%$ patients. Approximately, Males and female, respectively53.10 and 52.8\%, shown sinus tachycardia (ST arrythmia). PVC arrythmia was found in $2.9 \%$ of total patients. BBB arrythmia was found in $31.20 \%$ of males vs. $11.10 \%$ of females. The mean systole/diastole blood pressures respectively were $130 \pm 4 / 79.7 \pm 2$ in males and $134 \pm 4 / 81 \pm 3$ in females. Heart axis changes was identified in $43.8 \%$ and $27.8 \%$ of males and females respectively.

Conclusion: Severity of symptoms and outcomes of COVID-19 in cardiac patients showed some differences between men and women which could be associated with differences in immune responses, respiratory tract properties, renin angiotensin system, sex hormones and lifestyle. However, more studies to categorize gender differences are required.
\end{abstract}

Keywords: SARS-CoV-2, Cardiac disease, hypertension, COVID-19, Clinical features, Laboratory, ECG

\begin{abstract}
Citation: Mohammadyari E, Kaffashian MR, Ahmadi I, Kenarkoohi A, Soufinia A, Norozi S, Balavandi F, Ghaysouri A, Bastani E, Rizehbandi M, Karimian M, Fasihi M, Falahi S, Kalvandi G, Maleki M. Clinical Features of Novel Coronavirus 2019-Infected Cases with Pre-existing Cardiovascular disease, Disaggregated by Gender. Pak Heart J. 2021;54(02):180-185. DOI: https://doi.org/10.47144/phj.v54i2.2096
\end{abstract}

\section{INTRODUCTION}

The SARS-CoV-2 epidemic started in late December 2019 in China; the virus has been first emerged in Wuhan. ${ }^{1}$ SARS-CoV-2 causes respiratory disease and pneumonia and so it is called Severe Acute Respiratory Syndrome Coronavirus 2, SARS-CoV-2, and its related disease named Coronavirus Disease 2019, COVID-19. ${ }^{2}$ It is reported that SARS-CoV-2 shows a wide spectrum of the clinical consequences, including asymptomatic infection toward acute respiratory damage. ${ }^{2,3}$ The clinical symptoms of this infection have been observed heterogeneous but some are common at the onset of the disease; fever, dry cough, and shortness of breath. ${ }^{4}$

COVID-19 virus through S1 domain of spike protein on the virion, binds to the extracellular domain of Angiotensin converting enzyme
2(ACE2) in the cell membrane, then fusion of the viral and cell membranes occurs. Following that, viral RNA transfers its genome inside the cell; ultimately makes new virions that infects other cells. ${ }^{5}$ The receptor of ACE2 is almost present in the plasma membrane of all organs, including cardiovascular system. ${ }^{6}$ Its expression is reported in the endothelium of capillaries, vascular smooth muscles, coronary arteries, ventricular myocardium. ${ }^{7}$ Abnormal function of RAS is associated with the development of heart disease and hypertension. ${ }^{6}$ ACE inhibitors and angiotensin II receptor blockers (ARBs) are as routine drugs to treat some chronic diseases, like hypertension. ${ }^{6}$

It is reported that heart failure patients are prone to COVID-19 infection because of increased plasminogen level. ${ }^{6}$ Plasmin removes the extracellular domain of S-protein of the virus and elevates its affinity to bind with ACE2 and 
facilitates virus entry to the host cells. ${ }^{1}$ It is documented that, patients with disease like hypertension, cardiovascular and kidney disease, showed severe clinical outcomes when infected with COVID-19. ${ }^{8}$ Some studies have reported men are more sensitive to COVID-19 than female and showed more mortality rate $\mathrm{e}^{9,10}$ they may have more ACE2 receptor ${ }^{11}$ but Chen et al. reported that women are more protected against COVID-19 because of high tissue levels of ACE2. They reported that ACE2 levels are more in Asian females so they are infected less. ${ }^{12}$ Also, they explained that estrogen and testosterone modulate ACE2 expression levels. ${ }^{12}$ With this confliction this study was performed to evaluate the clinical features of 68 Novel Coronavirus 2019-infected cardiac cases in Ilam, IRAN and check whether the symptoms show any difference between men and women in these Coronavirus 2019-Infected cases with pre-existing cardiovascular diseases.

\section{METHODOLOGY}

A single-center, retrospective observational study was done at Mostafa Khomeini Hospital in Ilam Province, Iran, from January to March 2020.

Data of 68 Cardiac patients who diagnosed covid 19 infections were reviewed, after the approval of ethical committee of Ilam university of medical sciences, Ilam, Iran (Ethics ID: IR.MEDILAM.REC.1399.049). Data collection forms were reviewed by two researchers separately. The initial physical examination, the first signs and symptoms, pulse oximetry oxygen saturation $(\mathrm{O} 2$ SAT) and laboratory results, chest radiography and CT findings of 68 cardiac patients were evaluated and analyzed retrospectively. Blood group was also recorded.

Supportive oxygen therapies (through mask or tracheal intubation) were also described. Electrocardiograph (ECG) also analyzed.

Under safety conditions Nasopharyngeal and oropharyngeal sample collecting from the cases were done by experts, then samples were transferred to the special lab for coronavirus laboratory in the insulated boxes equipped with cool pack $\left(4{ }^{\circ} \mathrm{C}\right)$. The viral RNA was extracted from the sample, using the extraction of viral DNA/RNA kit (Favorgen Biotech Corporation, Taiwan) and kept at $-20^{\circ} \mathrm{C}$ to the time of test operation. PCR amplification was done in accordance to Sansure Biotech Inc. kit producer instruction (Changsha, China).

The specific primer and probe RT-PCR targeting ORF1ab and Nucleoprotein gene ( $\mathrm{N}$ genes) were utilized to detect the viral genomes of the SARSCoV-2 in patients' samples. As well as, internal control targeting the RNase $\mathrm{P}$ gene used for monitoring process sample collection and PCR reaction in order to minimize false-negative results. For the cycle's threshold (CT) values more than 40 cycles, the test result was reported as negative.

For real-time PCR reaction, first $30 \mu \mathrm{L}$ Master Mix and then $20 \mu \mathrm{L}$ of the extracted viral RNA were added into each well. PCR tubes were placed within the Mic Real-Time PCR System (Bio Molecular Systems, Australia). The rRT-PCR test was completely performed about $124 \mathrm{~min}$ and the fluorescent curves were observed to analyze the result. Positive results with a CT value less than 40 cycles confirmed the existence of SARS-CoV-2 RNA.

In each detection run, a negative control (no template) was used in order to check any contamination during the rRT-PCR procedure, as well, a positive template control used to observe whether the rRT-PCR process operated properly.

Statistical analyses were done using SPSS software version 17.0. $\mathrm{P}$ values less than 0.05 were considered statistically significant. Continuous measurements were presented as mean if they were normally distributed, or median (IQR), if they were not, and categorical variables were presented as count (\%). Laboratory results, also assessed whether the measurements were not in the normal values. Categorical variables have expressed as number (\%) and compared by $\chi^{2}$ or Fisher's exact and Mann Whitney tests between the groups.

\section{RESULTS}

This study consisted total 68 Cardiac patients with (rRT-PCR confirmed) SARS-CoV-2 infection referred to Ilam hospital. 52.9\% of the patients were female (vs. $47.1 \%$ male) (Table 1). The mean ages were $70.84 \pm 1.8$ and $68.72 \pm 1.7$ years in males and female patients respectively, with no significant differences. The youngest was 43-year female, and the oldest was 91-year male.

The most common symptoms at the beginning of illness were dry cough $(78 \%$ of male versus $80 \%$ females) and fever (62\% of male versus $75 \%$ females). The other signs and symptoms are presented in Table 1. Chest/Abdominal pain, hemoptysis, perspiration, and arthralgia were less common symptoms (Table1).

Patients' temperature range was 36 to $40.3{ }^{\circ} \mathrm{C} .75 \%$ of female and $62.5 \%$ of male had fever $\left(\geq 37.8^{\circ} \mathrm{C}\right)$ but there isn't any significant difference between two genders. $97 \%$ of febrile patients needed oxygen supplementation (100\% males versus $96 \%$ females) but there isn't any significant relationship between $\mathrm{O} 2$ and fever. $81 \%$ of afebrile patients also received oxygen. Mean $\mathrm{O} 2$ saturation in patients who did not 
received oxygen supplementation was $\geq 86 \%$. O2 saturation in patients with $\mathrm{O} 2$ therapy was $85 \%$ (without any significant difference between men and women) (table1). There isn't any difference between the ages of who required supplemental $\mathrm{O} 2$ compared with who did not require (69.7 vs. 69.6 years, p<0.98). $31 \%$ of men and $11 \%$ of women experienced intubation (significant difference between both genders).

Table 1: Clinical Symptoms of Patients with SARS-CoV-2 Infection

\begin{tabular}{|c|c|c|c|}
\hline Characteristics & Male & Female & \multirow{2}{*}{$\begin{array}{c}P \\
\text { value }\end{array}$} \\
\hline Total $(\mathbf{N})$ & $32(47.1)$ & $36(52.9)$ & \\
\hline $\begin{array}{l}\text { Age, mean (range) } \\
\text { years }\end{array}$ & $\begin{array}{c}70.84 \\
(49-91)\end{array}$ & $\begin{array}{c}68.72 \\
(43-90)\end{array}$ & 0.38 \\
\hline \multicolumn{4}{|c|}{ Symptoms on presentation, $\mathbf{N}(\%)$} \\
\hline Cough & $25(78.1)$ & $29(80.6)$ & 0.8 \\
\hline Fever & $20(62.5)$ & $27(75)$ & 0.26 \\
\hline dyspnea & $30(93.8)$ & $26(76.5)$ & 0.05 \\
\hline Myalgia & 15(46.9) & $13(36.1)$ & 0.37 \\
\hline Contusion & $10(31.3)$ & $8(22.2)$ & 0.4 \\
\hline Chills & $18(56.3)$ & $19(52.8)$ & 0.77 \\
\hline Headache & $7(21.9)$ & $6(16.7)$ & 0.59 \\
\hline Sore throat & $7(33.3)$ & $7(26.9)$ & 0.63 \\
\hline Rhinorrhea & $0(0)$ & $1(3.7)$ & 0.38 \\
\hline Vomiting & $8(25)$ & $9(25)$ & $\begin{array}{c}>0.99 \\
9\end{array}$ \\
\hline Diarrhea & $3(9.4)$ & $3(8.3)$ & 0.88 \\
\hline Nausea & $4(12.5)$ & $10(27.8)$ & 0.12 \\
\hline Arthralgia & $3(9.4)$ & $1(2.8)$ & 0.25 \\
\hline Conjunctivitis & $1(3.1)$ & $0(0)$ & 0.28 \\
\hline Loss of smell & $9(36)$ & $5(17.2)$ & 0.12 \\
\hline Loss of taste & $10(45.5)$ & $6(21.4)$ & 0.07 \\
\hline \multicolumn{4}{|c|}{ Vital sign at presentation, median(range) } \\
\hline Temperature, ${ }^{\circ} \mathrm{C}$ & $\begin{array}{c}37.30 \\
(36.2-39.5)\end{array}$ & $\begin{array}{c}37.32 \\
(36-40.3)\end{array}$ & 0.94 \\
\hline $\begin{array}{l}\text { Respiratory rate, } \\
\text { breaths/min }\end{array}$ & $\begin{array}{c}32 \\
(16-27)\end{array}$ & $\begin{array}{c}36 \\
(14-22)\end{array}$ & 0.97 \\
\hline $\begin{array}{l}\text { Pulse oximeter } \mathrm{O} 2 \\
\text { saturation, } \%\end{array}$ & $\begin{array}{l}85.78 \\
(63-95) \\
\end{array}$ & $\begin{array}{r}85.33 \\
(54-96) \\
\end{array}$ & 0.81 \\
\hline $\begin{array}{l}\text { Systolic blood } \\
\text { pressure, } \mathrm{mm} \mathrm{Hg}\end{array}$ & $\begin{array}{c}135 \\
(87-184) \\
\end{array}$ & $\begin{array}{c}130 \\
(75-190)\end{array}$ & 0.43 \\
\hline $\begin{array}{l}\text { Diastolic blood } \\
\text { pressure, } \mathrm{mm} \mathrm{Hg}\end{array}$ & $\begin{array}{c}79.69 \\
(54-100)\end{array}$ & $\begin{array}{c}81.19 \\
(35-125)\end{array}$ & 0.68 \\
\hline Heart rate, /min & $\begin{array}{c}89.63 \\
(55-120)\end{array}$ & $\begin{array}{c}88.92 \\
(68-140)\end{array}$ & 0.84 \\
\hline \multicolumn{4}{|c|}{ Chest CT Findings \% } \\
\hline X-Ray Pneumonia & $28(87.5)$ & $31(86.1)$ & 0.86 \\
\hline Lung inflammation & $3(15)$ & $3(11.5)$ & 0.73 \\
\hline \multicolumn{4}{|l|}{ Treatment, N (\%) } \\
\hline Oxygen therapy & $30(93.8)$ & $33(91.7)$ & 0.74 \\
\hline ICU & $10(31.3)$ & $8(22.2)$ & 0.4 \\
\hline Intubation & $10(31.3)$ & $4(11.1)$ & 0.04 \\
\hline \multicolumn{4}{|c|}{ Clinical outcome, N (\%) } \\
\hline Expired & $9(28.1)$ & $4(11.1)$ & \multirow{2}{*}{0.07} \\
\hline Discharge & $23(71.9)$ & $32(88.9)$ & \\
\hline
\end{tabular}

Leukocytopenia $(<3.5 \times 103$ per $\mu \mathrm{L})$ were presented in $2.8 \%$ females and $6.3 \%$ males and leukocytosis $(>9 \times 103$ per $\mu \mathrm{L})$ in $30 \%$ female and $37 \%$ males. Neutrophilia $(>70 \%)$ was observed in $75 \%$ both gender, lymphopenia in $38.9 \%$ females and 58.4 males $(<20 \%)$, and thrombocytopenia $(<150 \times 103$ per $\mu 1)$ was presented in $11.1 \%$ men and $18.8 \%$ women, without any significancy between genders. In $75 \%$ females and $56 \%$ Males, decrease in hemoglobin $(<13.5 \mathrm{gr} / \mathrm{dL})$ was detected (Table $2 \&$ $3)$. Serum creatinine and urea increased above the normal level respectively in 48 and $56 \%$ of males, versus 11 and $18 \%$ females). Troponin level was different between male and females $(\mathrm{p}<0.02)$. Table 2 shows the values of the relevant blood parameters in men and women separately.

Table 2: Laboratory Findings of Patients with SARS-CoV-2 Infection

\begin{tabular}{|c|c|c|c|}
\hline & Male & Female & $\begin{array}{c}\mathbf{P} \\
\text { value }\end{array}$ \\
\hline Total $(\mathbf{N})$ & $(n=32)$ & $(n=36)$ & - \\
\hline \multicolumn{4}{|c|}{ Blood routine, median(range) } \\
\hline $\begin{array}{l}\text { Red blood cell }(\times \text { per } \\
\mu \mathrm{l})\end{array}$ & $\begin{array}{l}4.40 \\
(2-6)\end{array}$ & $\begin{array}{l}4.30 \\
(3-5)\end{array}$ & 0.19 \\
\hline $\begin{array}{l}\text { Leucocytes }\left(\times 10^{3} \text { per }\right. \\
\mu 1 \text {; normal range: } 3 \cdot 5- \\
9 \text { ) }\end{array}$ & $\begin{array}{c}7.3 \\
(3.8-21)\end{array}$ & $\begin{array}{c}7.3 \\
(3.4-26)\end{array}$ & 0.91 \\
\hline $\begin{array}{l}\text { Neutrophils (\%; } \\
\text { normal range: } 40-70 \text { ) }\end{array}$ & $\begin{array}{c}80.50 \\
(65-90)\end{array}$ & $\begin{array}{c}75 \\
(60-91)\end{array}$ & 0.1 \\
\hline $\begin{array}{l}\text { Lymphocytes }(\% ; \\
\text { normal range: } 20-50)\end{array}$ & $\begin{array}{c}19 \\
(8-34)\end{array}$ & $\begin{array}{c}20 \\
(9-40) \\
\end{array}$ & 0.08 \\
\hline $\begin{array}{l}\text { Platelets }\left(\times 10^{3} \text { per } \mu 1 \text {; }\right. \\
\text { normal range } 150- \\
450)\end{array}$ & $\begin{array}{c}191 \\
(110-459)\end{array}$ & $\begin{array}{c}250 \\
(121-518)\end{array}$ & 0.035 \\
\hline $\begin{array}{l}\text { Hemoglobin }(\mathrm{g} / \mathrm{dl} ; \\
\text { normal range } 13.5-18)\end{array}$ & $\begin{array}{c}13.20 \\
(8-16)\end{array}$ & $\begin{array}{c}12.70 \\
(10-16)\end{array}$ & 0.19 \\
\hline \multicolumn{4}{|c|}{ Blood biochemistry, median(range) } \\
\hline $\begin{array}{l}\text { Serum creatinine } \\
\text { (mg/dl; normal range } \\
0.6-1.3)\end{array}$ & $\begin{array}{l}1.40 \\
(1-11)\end{array}$ & $\begin{array}{c}1 \\
(1-5)\end{array}$ & 0.01 \\
\hline $\begin{array}{l}\text { Urea }(\mathrm{mg} / \mathrm{dl} \text {; normal } \\
\text { range: } 11-55)\end{array}$ & $\begin{array}{c}53 \\
(1-251) \\
\end{array}$ & $\begin{array}{c}29 \\
(1-152) \\
\end{array}$ & 0.01 \\
\hline $\mathrm{Na}$ & $\begin{array}{c}136 \\
(130-153) \\
\end{array}$ & $\begin{array}{c}138 \\
(132-152) \\
\end{array}$ & 0.33 \\
\hline K & $\begin{array}{c}4 \\
(3-6)\end{array}$ & $\begin{array}{l}3.95 \\
(3-5) \\
\end{array}$ & 0.15 \\
\hline $\mathrm{Ca}$ & $\begin{array}{c}9.4 \\
(7.7-10.8)\end{array}$ & $\begin{array}{c}9.5 \\
(8.3-10.9)\end{array}$ & 0.13 \\
\hline
\end{tabular}

At the chest CT, the features of pneumonia were found in $86-87 \%$ men and women cardiac patient with COVID-19 (Table 1).

Most infected cardiac patient's blood group was A+ (43.90\% of total, $45.50 \%$ of males and $42.10 \%$ of females). There is not considerable difference between two genders from this view (Table 4).

Males and females patients, respectively 53.10 and $52.8 \%$ shown sinus tachycardia (ST arrythmia), with no significant differences among genders. Premature ventricular complex (PVC) was found in ECG of the $2.9 \%$ of total patients with no significant differences between genders. Bundle branch block (BBB) arrythmia was found in ECG of the $31.20 \%$ of males vs. $11.10 \%$ of females with significant differences between genders $(\mathrm{p}<0.05)$. Only one 
patient (male) showed myocardial infarction (MI) $(1.50 \%$ of total with no significance between genders).

Table 3: Laboratories changes of Patients with SARS-CoV-2 infection

\begin{tabular}{|l|c|c|c|c|}
\hline \multirow{2}{*}{} & \multicolumn{2}{|c|}{ Male } & \multicolumn{2}{c|}{ Female } \\
\cline { 2 - 5 } & $\begin{array}{l}\text { Increase } \\
\text { d }\end{array}$ & $\begin{array}{l}\text { Decreas } \\
\text { ed }\end{array}$ & $\begin{array}{l}\text { Increase } \\
\text { d }\end{array}$ & $\begin{array}{l}\text { Decreas } \\
\text { ed }\end{array}$ \\
\hline $\begin{array}{l}\text { Leucocytes }(\times \\
\left.10^{3} \text { per } \mu \mathrm{l}\right)\end{array}$ & $12(37.5)$ & $2(6.30)$ & $11(30.6)$ & $1(2.8)$ \\
\hline $\begin{array}{l}\text { Neutrophils } \\
(\%)\end{array}$ & $24(75.0)$ & 0 & $27(75.0)$ & 0 \\
\hline $\begin{array}{l}\text { Lymphocytes } \\
(\%)\end{array}$ & 0 & $\begin{array}{c}19(59.40 \\
)\end{array}$ & 0 & $14(38.9)$ \\
\hline $\begin{array}{l}\text { Platelets } \\
\left.10^{3} \text { per } \mu \mathrm{l}\right)\end{array}$ & 0 & $6(18)$ & 0 & $4(11.1)$ \\
\hline $\begin{array}{l}\text { Hemoglobin } \\
(\mathrm{g} / \mathrm{dl})\end{array}$ & 0 & $\begin{array}{c}18(56.30 \\
)\end{array}$ & 0 & $27(75)$ \\
\hline $\begin{array}{l}\text { Serum } \\
\text { creatinine } \\
(\mathrm{mg} / \mathrm{dl})\end{array}$ & $11(48.4)$ & 0 & $4(11.1)$ & 0 \\
\hline Urea $(\mathrm{mg} / \mathrm{dl})$ & $14(56.0)$ & 0 & $6(18.8)$ & 0 \\
\hline $\begin{array}{l}\text { Troponin } \\
(\mathrm{ng} / \mathrm{l})\end{array}$ & $4(12.5)$ & 0 & 0 & 0 \\
\hline
\end{tabular}

The mean systole and diastole blood pressures respectively were $130 \pm 4$ and $79.7 \pm 2$ in males and $134 \pm 4$ and $81 \pm 3$ in female patients, again with no significant differences between genders. The 43.80 and $27.8 \%$ of males and female patients respectively, shown heart axis changes, with no significant differences among genders (Table 4).

Table 4: Blood groups and Electrocardiographic findings of Patients with SARS-CoV-2 Infection

\begin{tabular}{|c|c|c|c|}
\hline & Male & Female & P-value \\
\hline \multicolumn{4}{|l|}{ Blood groups } \\
\hline $\mathrm{A}+$ & $45.50 \%$ & $42.10 \%$ & \multirow{7}{*}{-} \\
\hline A- & 0 & $10.50 \%$ & \\
\hline $\mathrm{B}+$ & $13.60 \%$ & $26.30 \%$ & \\
\hline B- & $4.50 \%$ & 0 & \\
\hline $\mathrm{O}+$ & $27.30 \%$ & $21.10 \%$ & \\
\hline $\mathrm{O}-$ & $4.50 \%$ & 0 & \\
\hline $\mathrm{AB}+$ & $4.50 \%$ & 0 & \\
\hline \multicolumn{4}{|c|}{ Electrocardiographic findings } \\
\hline ST arrhythmia & $17(53.10 \%)$ & $19(52.80 \%)$ & 0.58 \\
\hline PVC & $1(3.10 \%)$ & $1(2.80 \%)$ & 0.72 \\
\hline MI & $1(3.10 \%)$ & 0 & 0.47 \\
\hline \multicolumn{4}{|l|}{ BBB } \\
\hline LBBB & $6(18.80 \%)$ & $4(11.10 \%)$ & \multirow{2}{*}{0.049} \\
\hline RBBB & $4(12.50 \%)$ & 0 & \\
\hline
\end{tabular}

Of 68 patients $11 \%$ of females and $28 \%$ of males died, and the others discharged. Most of them were male. The mean age of expired patients was 72 with a range of (49-91) years. The medians of body temperature (37.34) and respiratory rate (18.23) of these patients were not significantly more than survived ones, and the $\mathrm{O} 2$ saturation detected by pulse oximeter was significantly less in these patients than survived ones $(79.23 \%, \mathrm{p}<0.01)$.

\section{DISCUSSION}

It has been pointed out that the association between hypertension and COVID 19 infections is likely due to their association with ACE II enzyme, ${ }^{13}$ addition to hypertension, other cardiovascular comorbidities were also frequently reported in patients with severe cases of COVID 19. ${ }^{13}$ Patients with pre-existing heart failure are more likely to have elevated ACE II expression which can increase the risk of infection. ${ }^{13}$ The present study revealed the prevalence of COVID-19 in male cardiac patients are little more dominant than females. Also, in the dead cases, men were more than women. Based on other studies, also male patients were more than female patients. ${ }^{14}$ There are many differences between both genders in the immune response to SARS-CoV infection and inflammatory diseases, and stated females, compared to males, are less susceptible to viral infection, because of difference in the innate immunity, their steroidal hormones and some factors associated with sex chromosomes. ${ }^{11}$ A pair of $\mathrm{X}$ chromosomes in women supports the immune system and causes lower viral load, and less inflammation than in man. ${ }^{11}$

Most common clinical symptoms in male and female cardiac cases were cough, fever, dyspnea, and chills. Based on meta-analysis study generally fever in about 88 $\%$, cough in $57 \%$, and dyspnea in $45 \%$ of patients were reported as the most prevalent clinical symptoms. ${ }^{15}$

In our study, Leukocytopenia was observed in $2.8 \%$ of females and $6.3 \%$ of males and leukocytosis in $30 \%$ of female and $37 \%$ of males. Neutrophilia was observed in $75 \%$ of both genders, lymphopenia in $38.9 \%$ of females and $58.4 \%$ of males, and thrombocytopenia was presented in $11.1 \%$ of men and $18.8 \%$ of women, without any significance between genders.

Generally, a study expressed that almost $19 \%$ of patients with covid-19 shown leukocytopenia, and 17\%, leukocytosis, and $43 \%$ shown lymphopenia. SARS$\mathrm{CoV}-2$ induces lymphopenia probably via acting against lymphocytes, chiefly $\mathrm{T}$ cell. Spreading the virus via respiratory system, and infection the cells lead to increased cytokine releasing and induce sequences of immunity reactions causing change in lymphocytes. ${ }^{15} \mathrm{In}$ a study $5 \%$ of patients showed less than $100 \times 10^{9}$ platelet/L. ${ }^{16}$ But the other study reported a normal median range for platelet. ${ }^{17}$

Decrease in hemoglobin was detected in $75 \%$ of females and $56 \%$ of Males, like our study, decreased hemoglobin levels were shown by Chen and colleagues $(51 \%),{ }^{18}$ but the normal hemoglobin levels also reported in some study on SARS-CoV-2 infected patients. ${ }^{19}$ Percentage change of hemoglobin levels also may relate to the basic levels of hemoglobin and anemia in every area. ${ }^{20}$ Serum creatinine and urea increased above the normal levels 
respectively in 48 and $56 \%$ of males (versus 11 and $18 \%$ of females). BUN was increased in $6 \%$ and creatinine level, in $3 \%$ of covid-19 cases in a study. ${ }^{18}$ But normal median levels also were reported in severe cases of a study. ${ }^{14}$ A study in Iran reported that creatinine and urea respectively increased in 14 and $10 \%$ of their cases, in spite normal median range, also this study reported high levels of serum creatinine and urea in severe cases. ${ }^{20}$

Troponin level was different between male and females, $12.5 \%$ of males shown increased levels of troponin. Arentz et al. shown that high troponin levels in $14 \%$ of their patient (> $300 \mathrm{ng} / \mathrm{l}$ ); it indicates cardiac injuries; ${ }^{19}$ in a study $31 \%$ of ICU cases showed high troponin levels. ${ }^{21}$ Based on our study lymphopenia, neutrophilia, thrombocytopenia, high serum BUN and creatinine levels which declare that COVID-19 infection might be related to the cell immune deficiencies and renal injuries in these cardiac patients.

Most infected cardiac patients' blood group was A+. A study on 557 individuals with COVID-19 in Sudan reported that Rhesus-positive $(\mathrm{A}+)$ individuals were the most vulnerable. ${ }^{22}$ Of course, it should not be forgotten that $\mathrm{A}+$ is one of the most common blood types in the population.

Over $50 \%$ of males and female patients has shown ST arrythmia, with no significant differences among genders. BBB arrythmia was almost found in ECG of the $31.20 \%$ of males vs. $11.10 \%$ of females with significant differences between genders. The 43.80 and $27.8 \%$ of males and female patients respectively, shown heart axis changes. Based on studies occurrence of arrhythmias among COVID-19 cases who are clinically stable is low. ${ }^{23}$ In these cases, arrhythmias may result from hypoxia because of direct effects of SARS-CoV-2 on lung tissue, myocarditis, and also unusual immune reactions. ${ }^{24}$ In accordance with this, over $90 \%$ of our patients needed oxygen therapy because of hypoxia and the Mean $\mathrm{O} 2$ saturation in our patients with $\mathrm{O} 2$ therapy or not was $85-86 \%$; furthermore $31 \%$ of men and $11 \%$ of women experienced invasive mechanical ventilation. Also, it is stated that arrhythmias could result from other situations such as myocardial ischemia, myocardial strain, disturbing fluid and electrolytes balance, and medicines side effect. As well Arrhythmias may appear in presence of systemic diseases, not with direct effect of SARS-CoV-2 infection. ${ }^{24}$ It should be mentioned that heart axis changes might directly cause by our patients' chronic cardiac disease and hypertension.

Our study shown pneumonia were found in $86-87 \%$ men and women cardiac patient with covid19. Also, the other studies reported bilateral pneumonia and ground-glass opacities on chest CT scans of patient with SARS-CoV2 infection. ${ }^{25}$

At last, in our study, 13 patients died (11\% of females and $28 \%$ of males). This is different among studies. O2 saturation in deceased patients was significantly less than in survived ones (79.23\%). A study has reported $19 \%$ of hospitalized patients died and surprisingly all of the expired cases were male with ages over 50 years. ${ }^{14} \mathrm{~A}$ meta-analysis study showed $13.9 \%$ non-survived cases among hospitalized ones. ${ }^{15}$

\section{CONCLUSION}

Cardiac diseases and hypertension are probably among the most sensitive and high-risk groups for COVID-19 disease. Clinical symptoms reported among COVID-19 patients with pre-existing cardiovascular disease have a wide range. Based on this study the severity of symptoms and outcomes of COVID-19 in cardiac patients showed some differences between men and women which could be related to differences in immune responses, respiratory tract properties, renin angiotensin system, sex hormones and lifestyle. However, more studies and follow-up of patients in terms of final results and identification gender differences in this group of patients are required.

\section{AUTHORS' CONTRIBUTION}

EM: Concept and design, data acquisition, interpretation, drafting, final approval, and agree to be accountable for all aspects of the work. MRK, IA, AK, AS, SN, FB, AG, $\mathrm{EB}, \mathrm{MR}, \mathrm{MK}, \mathrm{MF}, \mathrm{SF}, \mathrm{GK}, \mathrm{MM}$ : Data acquisition, interpretation, drafting, final approval and agree to be accountable for all aspects of the work.

Conflict of interest: Authors declared no conflict of interest.

Source of Funding: This study was supported by Ilam University of Medical Sciences, Ilam, Iran.

\section{REFERENCES}

1. Lam TT-Y, Jia N, Zhang Y-W, Shum MH-H, Jiang J-F, Zhu H-C, et al. Identifying SARS-CoV-2-related coronaviruses in Malayan pangolins. Nature. 2020:1-4.

2. Jiang F, Deng L, Zhang L, Cai Y, Cheung CW, Xia Z. Review of the clinical characteristics of coronavirus disease 2019 (COVID19). J Gen Intern Med. 2020;35(5):1545-9.

3. Chang L, Yan Y, Wang L. Coronavirus disease 2019: coronaviruses and blood safety. Transfus Med Rev. 2020;34(2):75-80.

4. Poon LL, Peiris M. Emergence of a novel human coronavirus threatening human health. Nature Med. 2020;26(3):317-9.

5. Kruse RL. Therapeutic strategies in an outbreak scenario to treat the novel coronavirus originating in Wuhan, China. F1000Res. 2020;9:72.

6. Kenarkoohi A, Maleki M, Safari T, Kafashian M, Saljoughi F, Sohrabipour S. Angiotensin-converting Enzyme 2 roles in the Pathogenesis of COVID-19. Curr Hypertens Rev. 2020. DOI: 10.2174/1573402116666200810134702 [Online ahead of print]

7. Li XC, Zhang J, Zhuo JL. The vasoprotective axes of the reninangiotensin system: physiological relevance and therapeutic implications in cardiovascular, hypertensive and kidney diseases. Pharmacol Res. 2017;125:21-38.

8. Ji H-L, Zhao R, Matalon S, Matthay MA. Elevated plasmin (ogen) as a common risk factor for COVID-19 susceptibility. Physiol Rev. 2020;100(3):1065-75.

9. Wan S, Li M, Ye Z, Yang C, Cai Q, Duan S, et al. CT manifestations and clinical characteristics of 1115 patients with 
coronavirus disease 2019 (COVID-19): A systematic review and meta-analysis. Acad Radiol. 2020;27(7):910-21.

10. Falahi S, Kenarkoohi A. Sex and gender differences in the outcome of patients with COVID- 19. J Med Virol. 2021;93(1):151-2.

11. Conti P, Younes A. Coronavirus COV-19/SARS-CoV-2 affects women less than men: clinical response to viral infection. J Biol Regul Homeost Agents. 2020;34(2):71.

12. Chen J, Jiang Q, Xia X, Liu K, Yu Z, Tao W, et al. Individual variation of the SARS- CoV- 2 receptor ACE2 gene expression and regulation. Aging Cell. 2020;19(7):e13168.

13. Cancarevic I, Malik BH. SARS-CoV-2 (COVID 19) Infection in hypertensive patients and in patients with cardiac disease. Cureus. 2020;12(6):e8557.

14. Chen G, Wu D, Guo W, Cao Y, Huang D, Wang H, et al. Clinical and immunological features of severe and moderate coronavirus disease 2019. J Clin Invest. 2020;130(5):2620-9.

15. Rodriguez-Morales AJ, Cardona-Ospina JA, Gutiérrez-Ocampo E, Villamizar-Peña R, Holguin-Rivera Y, Escalera-Antezana JP, et al. Clinical, laboratory and imaging features of COVID-19: A systematic review and meta-analysis. Travel Med Infect Dis. 2020;34:101623.

16. Yang X, Yu Y, Xu J, Shu H, Liu H, Wu Y, et al. Clinical course and outcomes of critically ill patients with SARS-CoV-2 pneumonia in Wuhan, China: a single-centered, retrospective, observational study. Lancet Respir Med. 2020;8(5):475-81.

17. Wong JE, Leo YS, Tan CC. COVID-19 in Singapore - current experience: critical global issues that require attention and action. JAMA. 2020;323(13):1243-4.

18. Chen N, Zhou M, Dong X, Qu J, Gong F, Han Y, et al. Epidemiological and clinical characteristics of 99 cases of 2019 novel coronavirus pneumonia in Wuhan, China: a descriptive study. Lancet. 2020;395(10223):507-13.

19. Arentz M, Yim E, Klaff L, Lokhandwala S, Riedo FX, Chong M, et al. Characteristics and outcomes of 21 critically ill patients with COVID-19 in Washington State. JAMA. 2020;323(16):1612-4.

20. Jarineshin H, Saljoughi F, Estabraghnia Babaki H, Hassaniazad M, Ghanbarnejad A, Sohrabipour S. Clinical features of 50 cases of 2019 novel coronavirus in Bandar Abbas, Iran. Med J Islamic Rep Iran.35(1):50-9.

21. Huang C, Wang Y, Li X, Ren L, Zhao J, Hu Y, et al. Clinical features of patients infected with 2019 novel coronavirus in Wuhan, China. Lancet. 2020;395(10223):497-506.

22. Taha SAH, Osman MEM, Abdoelkarim EAA, Holie MAI, Elbasheir MM, Abuzeid NMK, et al. Individuals with a Rhpositive but not Rh-negative blood group are more vulnerable to SARS-CoV-2 infection: demographics and trend study on COVID-19 cases in Sudan. New Microbes New Infect. 2020;38:100763.

23. Sala S, Peretto G, De Luca G, Farina N, Campochiaro C, Tresoldi $\mathrm{M}$, et al. Low prevalence of arrhythmias in clinically stable COVID- 19 patients. Pacing Clin Electrophysiol. 2020;43(8):891-3.

24. Kochav SM, Coromilas E, Nalbandian A, Ranard LS, Gupta A, Chung MK, et al. Cardiac Arrhythmias in COVID-19 Infection. Circ Arrhythm Electrophysiol. 2020;13(6):e008719.

25. Wang D, Hu B, Hu C, Zhu F, Liu X, Zhang J, et al. Clinical characteristics of 138 hospitalized patients with 2019 novel coronavirus-infected pneumonia in Wuhan, China. JAMA. 2020;323(11):1061-9.

\section{Address for Correspondence:}

Dr. Maryam Maleki, Department of Physiology, Faculty of Medicine, Ilam University of Medical Sciences, Ilam, Iran.

Email: maryammaleki777@yahoo.com 